\title{
ZooNom: an online thesaurus for alleviating ambiguity in the terminology of zoological nomenclature
}

\author{
ELIE MARIO SALIBA ${ }^{1 *}$, RÉGINE VIGNES-LEBBE ${ }^{1,2}$, ALAIN DUBOIS $^{1,3} \&$ ANNEMARIE OHLER ${ }^{1,4}$ \\ ${ }^{1}$ Institut de Systématique, Évolution, Biodiversité (ISYEB), Muséum national d'Histoire naturelle, CNRS, Sorbonne Université, EPHE, \\ UA, 57 rue Cuvier, F-75005, Paris (France). \\ 2 " regine.vignes-lebbe@mnhn.fr; @ https://orcid.org/0000-0002-6912-6248 \\ ${ }^{3}$ ”"alain.dubois@mnhn.fr; ; https://orcid.org/0000-0002-6463-3435

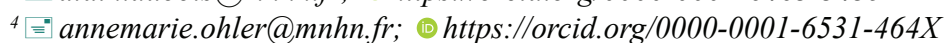 \\ ${ }^{*}$ Corresponding author. E"elie.saliba@mnhn.fr; 내ttps://orcid.org/0000-0001-9591-5016
}

\begin{abstract}
Zoological nomenclature is the discipline of taxonomy responsible for regulating the scientific names of animal species. It has its roots in Carolus Linnaeus' work and has been governed by an international Code since the turn of the $20^{\text {th }}$ century. Its vocabulary, on the other hand, is not always clear. Various authors have established new terminology in order to reduce ambiguity. To make these new terms, but also the classical terms used by the International Code of Zoological Nomenclature, accessible, an electronic thesaurus (link: https://www.loterre.fr/skosmos/FM8/en/) was created, allowing to compare existing terminologies. This thesaurus is also a tool for reflection and discussion, targeting taxonomists and experts in nomenclature.
\end{abstract}

Key words: Concepts, Vocabulary, SKOS

\section{Introduction}

Communicating is an essential part of the work of scientists, whether with peers or with society as a whole. In the field of life sciences, especially when it comes to taxonomy, ecology, genetics and population biology, being able to clearly designate an organism or a group of organisms is crucial.

Zoological nomenclature is the scientific discipline devoted to the unambiguous naming of animal taxa. It was initiated by Carolus Linnaeus, and its starting point was fixed at the tenth edition of his Systema naturae (Linnaeus 1758), making it more than 260 years old. Zoological nomenclature (or onymology), as a discipline, is used by scientists, as is its derived result, also called a nomenclature. The latter is also in use in legal texts, public databases and conservation policy documents. Its methodology is regulated by the International Code of Zoological Nomenclature, or the Code (Anonymous 1999, 2012). The International Commission on Zoological Nomenclature (the Commission) is in charge of its redaction and management.

Questions and exchanges on platforms such as Taxacom (http://mailman.nhm.ku.edu/cgi-bin/mailman/listinfo/ taxacom) are often linked to the misunderstanding of concepts of this discipline. Zoological nomenclature, also known as Linnaean zoological nomenclature, associates a name in a Latinized form to a taxon (a classification unit, concept proper to the scientific discipline of taxonomy) in a given classification. Its underlying structure is the Linnaean classification, which makes use of ranks. The Code recognizes nine main ranks (as well as potential additional ones), and has authority only on the names assigned in between the most inclusive (superfamily) and the least inclusive (subspecies) of these ranks. The main ranks, in descending order, are: superfamily, family, subfamily, tribe, subtribe, genus, subgenus, species and subspecies (Anonymous 1999). These ranks belong to three nomenclatural groups, also called nominal series, namely the family series, ranging from superfamily to subtribe; the genus series, covering any name assigned to the genus and subgenus ranks and the species series, for any name designating a species, a subspecies or an aggregate of species or subspecies (Anonymous 1999). At the species level, the 
name is a double complex composed of the generic and specific names. This is known as the Principle of Binominal Nomenclature (Anonymous 1999). The term binominal nomenclature is sometimes used as a synonym of Linnaean nomenclature.

It is important to highlight the fact that the structure of zoological nomenclature was developed throughout centuries. From Linnaeus' works, through the propositions of Strickland et al. (1843) and Blanchard's Règles (Blanchard 1905) to the last edition of the Code (Anonymous 1999, 2012), zoological nomenclature acquired its own traditions, usages and vocabulary. Considering its vocabulary and terms, the Code, for example, has an English and a French glossaries. The English glossary has approximately 360 entries.

\section{The vocabulary of zoological nomenclature}

The vocabulary of zoological nomenclature, having been constituted over a period of more than two centuries and a half, carries a heritage that is sometimes perceived as obsolete, or is misunderstood. The most well-known example is the "type" or "name-bearing type" concept. It is usually used to designates the physical specimen(s) that bear(s) the scientific Latin name of a taxon of the species series (species or subspecies). In the genus and family series, types are not specimens but nominal taxa (nominal types), respectively of the species or genus series - which ultimately refer to the specimens that are types of the nominal species concerned. Nomenclatural types are often mistaken for perfect models, representatives of their taxa, carrying the decisive (morphological) characters of their kinds (Farber 1976). The Code allows any specimen and any (available) name to be used as a type, as long as it belongs to the taxon it "typifies". The species series type plays the essential role of anchoring a name in the reality of material specimens and animal populations (Dubois \& Ohler 1996). In all the nominal series, types are essential in the management of the names in case of conflict.

Another important example is the distinction between two kinds of synonymies, i.e., the fact that a taxon has two or more names assigned to it. The first one is "subjective synonymy", and happens when two names, based on different types, are deemed to designate the same taxon by the subjective taxonomic decision of an author. The second one, called "objective synonymy" happens when two names are based on the same type. In both cases, among these two names, the older one (the senior synonym) is potentially (if not invalid for another reason) considered valid (i.e., the correct one to use under the rules of the Code) under the Principle of Priority (Anonymous 1999). Even though these two concepts seem similar, and are usually treated indifferently as "synonyms" in biodiversity or genetic databases, they actually are not. The first kind of synonyms is potentially valid, if a taxonomy separates the two designated taxa, while a junior objective synonym always remains invalid, and thus should not be used to designate a taxon (unless its senior synonym is itself invalid — e.g. by being preoccupied and thus a junior homonym —or unless the Commission exceptionally acts on it) (Anonymous 1999).

The confusion created by the misuses of these and other terms led some authors to design a more precise vocabulary. The term "onomatophore" (Simpson 1940) has been proposed to replace "type", keeping only the essential name-bearing quality of the entity (ővo $\mu \alpha$ [onoma], name — $\varphi \dot{\varepsilon} \rho \omega$ [phero], I bear, I carry), leaving aside the notion of "model". Several other terms were also created and cover different domains of zoological nomenclature, even the most controversial ones - e.g. aspidonym, for a scientific name protected from "taxonomic vandalism" (Wüster et al. 2021).

These terms published over decades by various authors in various sources are not always easily accessible. To overcome this situation, all the terms found during this work were analyzed and assembled in a thesaurus of zoological nomenclature (called ZooNom) and made available online. Unlike NOMEN (Dmitriev \& Yoder 2020), an ontology covering all biological names based on the official Codes of their respective disciplines, ZooNom focuses only on zoological nomenclature and on the diversity of terms that have been coined in this discipline, even outside of the official Code.

\section{Methods}

ZooNom is a controlled vocabulary in the form of a thesaurus. The World Wide Web Consortium presents vocabularies as follows: "On the Semantic Web, vocabularies define the concepts and relationships [...] used to describe 
and represent an area of concern" (Anonymous 2015) and a thesaurus as a structure that "identifies and describes, through natural language and other informal means, a set of distinct ideas or meanings" (Anonymous 2009). It was built using Opentheso (Rousset 2021), an open-source thesaurus-making software. It complies with the most recent standards i.e., ISO 25964-1: 2011 and ISO 25964-2: 2013. The thesaurus is accessible online through the LOTERRE platform (Linked Open TERminology REssources). It was built following the Essential Thesaurus Construction guidelines (Broughton 2006).

The search for terms was conducted in 58 publications (Appendix 1), including the Code and the articles referencing A. Dubois' vocabulary, as well as publications from other authors introducing new nomenclatural terms. D. L. Hawksworth's Terms used in bionomenclature (Hawksworth 2010) was also consulted, but only part of the terms proposed are included at this point. In fact, Hawksworth presents terms that come from different nomenclatural disciplines, some that are considered obsolete and other that are simply comical e.g. "vampirotype: (zool[ogy]., unoff[icial].) a type specimen, usually an insect, mounted with an oversized pin for the size of the specimen so that it appears impaled (!)"(p. 209). As he does not provide an exact bibliography, further terms are to be added on a case by case basis after a thorough additional research.

The bibliography of the thesaurus is documented on its main webpage. The collected terms were classified in semantic sets (called 'collections' on Opentheso and 'groups' on LOTERRE), 20 in total (Table 1), and aggregated in semantic units—called 'concepts' by the World Wide Web Consortium (Anonymous 2009).

TABLE 1. The twenty semantic collections of the ZooNom thesaurus in alphabetical order.

\begin{tabular}{|c|c|c|c|}
\hline $\begin{array}{l}\text { Name of the } \\
\text { collection }\end{array}$ & Definition & $\begin{array}{l}\text { Name of the } \\
\text { collection }\end{array}$ & Definition \\
\hline $\begin{array}{l}\text { Allocation and } \\
\text { Identification }\end{array}$ & $\begin{array}{l}\text { The set of terms relating to the designa- } \\
\text { tion and identification of a type }\end{array}$ & $\begin{array}{l}\text { Nomenclature } \\
\text { Theory }\end{array}$ & $\begin{array}{l}\text { The lexical field related to the theory } \\
\text { of nomenclature and the theoretical } \\
\text { concepts of this discipline }\end{array}$ \\
\hline $\begin{array}{l}\text { Assignment of } \\
\text { Nomina to Ranks }\end{array}$ & $\begin{array}{l}\text { The vocabulary referring to the assign- } \\
\text { ment of a name to a nomenclatural rank } \\
\text { and the properties of these ranks }\end{array}$ & $\begin{array}{l}\text { Priority and Us- } \\
\text { age }\end{array}$ & $\begin{array}{l}\text { All the terms referring to the concepts } \\
\text { of priority and usage }\end{array}$ \\
\hline Availability & $\begin{array}{l}\text { All terms relating to the lexical field of } \\
\text { availability in zoological nomenclature }\end{array}$ & Registration & $\begin{array}{l}\text { The lexical field related to registra- } \\
\text { tion and nomenclatural databases }\end{array}$ \\
\hline Classification & $\begin{array}{l}\text { All the rank names used in nomen- } \\
\text { clature, in addition to the vocabulary } \\
\text { around the notion of animal }\end{array}$ & $\begin{array}{l}\text { Relationships } \\
\text { between taxa }\end{array}$ & $\begin{array}{l}\text { All terms that relate to the position } \\
\text { of one taxon relative to another in a } \\
\text { classification }\end{array}$ \\
\hline First reviser & $\begin{array}{l}\text { The set of terms that relate to the first } \\
\text { reviser and the first reviser action }\end{array}$ & Spelling & $\begin{array}{l}\text { All terms relating to the lexical field } \\
\text { of spelling in zoological nomencla- } \\
\text { ture }\end{array}$ \\
\hline Homonymy & $\begin{array}{l}\text { All the terms that relate to the notion of } \\
\text { homonymy }\end{array}$ & Synonymy & $\begin{array}{l}\text { All the terms that relate to the notion } \\
\text { of synonymy }\end{array}$ \\
\hline $\begin{array}{l}\text { Languages and } \\
\text { Grammar }\end{array}$ & $\begin{array}{l}\text { The set of terms that relate to the lan- } \\
\text { guages of zoological nomenclature and } \\
\text { to the grammar and spelling rules that } \\
\text { apply to them }\end{array}$ & Taxonomy & $\begin{array}{l}\text { All terms that relate to taxonomy, di- } \\
\text { agnosis, and nomenclatural treatment } \\
\text { of a given taxonomy }\end{array}$ \\
\hline Locality & The lexical field related to type-locality & $\begin{array}{l}\text { The Code and the } \\
\text { Commission }\end{array}$ & $\begin{array}{l}\text { All the terms specific to the structure } \\
\text { of the Code, and to the publications } \\
\text { and actions of the Commission }\end{array}$ \\
\hline Names & $\begin{array}{l}\text { All the terms referring to names and the } \\
\text { vocabulary that describe them }\end{array}$ & Types & $\begin{array}{l}\text { All the terms around the concept of } \\
\text { name-bearing type }\end{array}$ \\
\hline $\begin{array}{l}\text { Nomenclatural } \\
\text { publications }\end{array}$ & $\begin{array}{l}\text { All the vocabulary surrounding scien- } \\
\text { tific publications, authors and publica- } \\
\text { tion media }\end{array}$ & Validity & $\begin{array}{l}\text { All terms relating to the lexical field } \\
\text { of validity in zoological nomenclature }\end{array}$ \\
\hline
\end{tabular}


A concept is named by a preferred English term. The criteria for the choice for the preferred term are: (1) the fact that the term is an alternative to the Code's, as this thesaurus aims to give them visibility; (2) the fact that the term is introduced with its own definition; (3) similarly to the Code's Principle of Priority, in case of multiple possible terms, the older one prevails. A crosslinking with NOMEN, for the relevant terms, has been introduced with the 1.3 version..

Each concept also contains the synonyms, abbreviations, other terms of the same word family and, if relevant, different spellings. With each concept comes its definition and its Code equivalent term and definition, if existing. If more than one definition is attached to the concept, the Code definition is placed in the application note field for ease of reading, and other definitions stay in the definition field, in order of priority. Furthermore, and if relevant, its etymology, its translation in French, the author of the term and/or the definition as well as the bibliographical source are also cited. The concepts were then put in a vertical hierarchy (a "broader concept" containing a "narrower concept") and linked to one another horizontally ("related concept") for ease of use and navigation (see fig. 1).

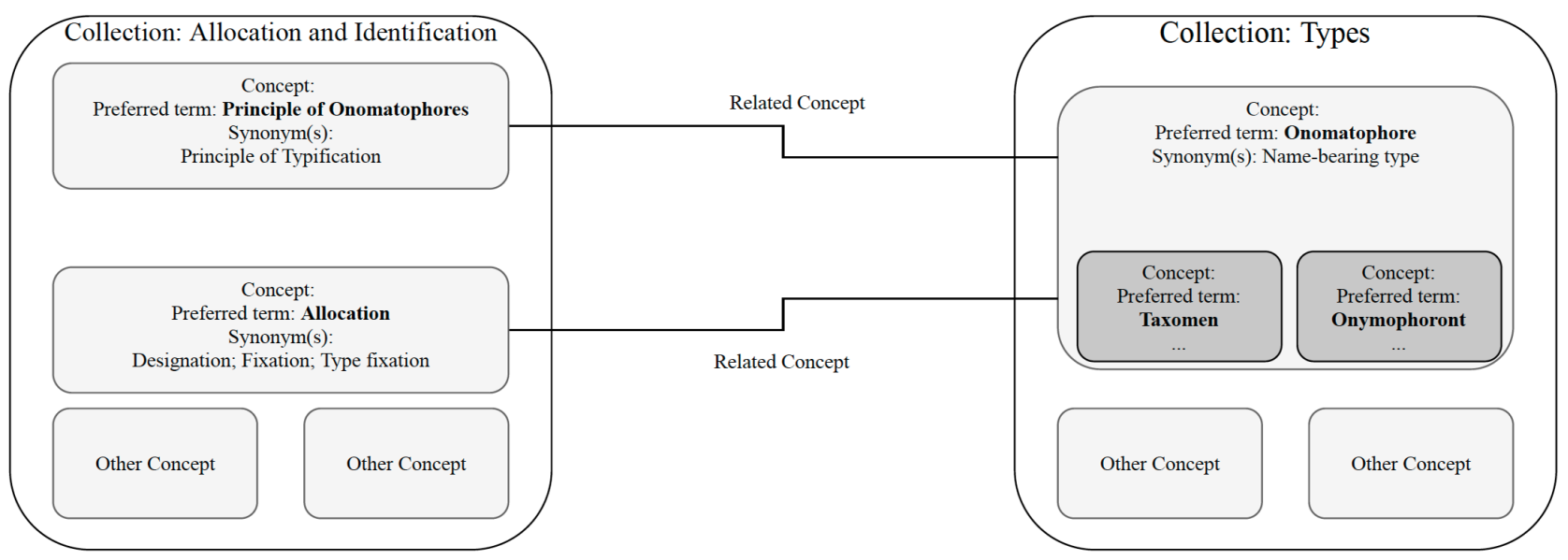

FIGURE 1. A simplified visualization of the structure of the thesaurus, with the example of the concept "Onomatophore". The color gets darker for every entity contained ("narrower") in another.

\section{Results}

Currently, the ZooNom thesaurus (fig. 2) is findable at https://www.loterre.fr/skosmos/FM8/en/ in its 1.3 version. It contains 929 terms (excluding terms from the same word families, like plurals), distributed across 798 concepts, 406 etymologies and 60 references. It covers every aspects of zoological nomenclature, from theoretical nomenclature to database registration of names, as well as languages and grammar.

The thesaurus can be used as a classical glossary, using the search bar, or the alphabetical order, but that's not all it has to offer. Gathering different terms under one same concept also offers the possibility to compare the terminologies, and thus to choose an optimal equivalent term. For example, subjective synonym would lead to doxisonym, and objective synonym to isonym (Dubois 2000). Even though the definitions are quite close, distinguishing the two situations with precise and different words can help reduce the tendency of mixing them up. Keeping this difference in mind would result in clearer biodiversity databases. Synonymic lists would then differentiate between names that can potentially designate another independent taxon and those which cannot.

Moreover, thanks to the hierarchical structure of the thesaurus, one can find a more precise term for a given nomenclatural situation. For example, under the concept onomatophore, as a "narrower concept", one can find the concept onymophoront (Dubois 2005), which applies strictly to a type specimen and not a nominal type.

In terms of machine-actionability, this thesaurus can be useful in tagging correctly, and in a non-ambiguous way, different cases and stages of decisions in the reasoning path of nomenclature.

\section{Curation and call for submission of terms}

ZooNom is destined to be updated at least once a year. Any new concepts proposals are highly welcomed, if relevant. For this, we require the new candidate term, its definition, the bibliographic reference, and if possible, the 
etymology. We are especially interested in terms frequently used in a part of the taxonomic community, or associated with a certain taxon, but unfamiliar or unknown outside of these applications.

Zoological Nomenclature Thesaurus _ + $\quad$ content language English - _ $\quad$ Search

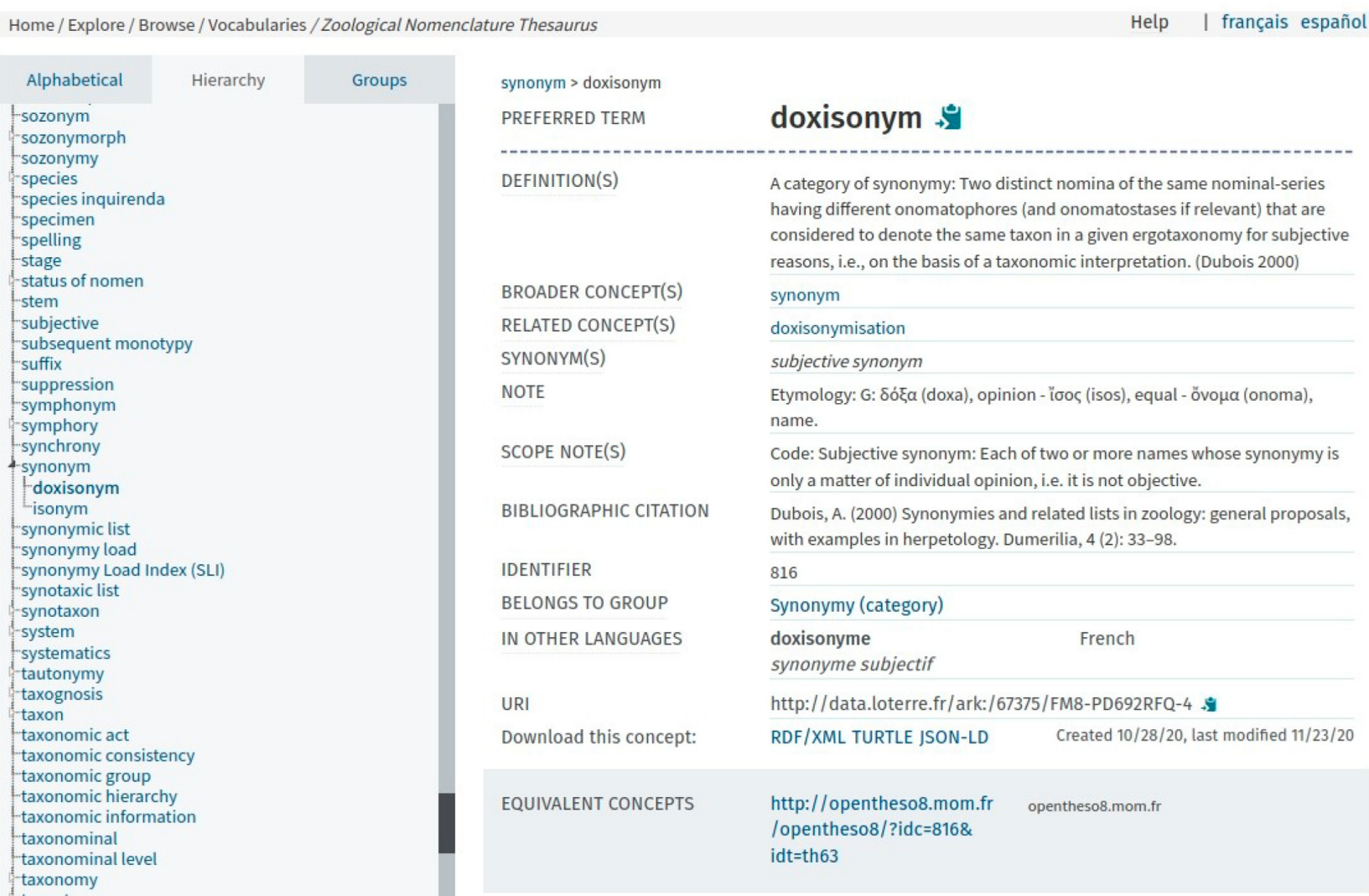

FIGURE 2. A screenshot of ZooNom taken on 10/11/2021. The concept shown is "doxisonym" (URL: https://www.loterre.fr/ skosmos/FM8/en/page/-PD692RFQ-4). The "note" field contains the etymology, and the "scope note" field presents the Code's equivalent (objective synonym) and definition.

\section{Conclusion and perspectives}

We hope that this thesaurus can be a reference for the terminology of zoological nomenclature, for both beginners and experts. This compilation of the concepts that covers zoological nomenclature could also be a medium in the process of computerization of the Code's rules that govern this discipline, or the development of better data mining tools. Unlike humans, computers are not capable of managing ambiguity. As a matter of fact, having the most precise vocabulary and circumscribed concepts is crucial in applying the nomenclatural procedure to the machine, be it in programming, in databases and or in the field of Semantic Web.

\section{Acknowledgments and funding}

The authors would like to thank Miled Rousset (Maison de l'Orient et de la Méditerranée) for his help in the computerization process, the LOTERRE team for their technical help and recommendations, and two anonymous referees for their comments. This work was awarded the 2020 Prix Jacques Lebbe of the Société Française de Sys- 
tématique, and was presented to the Taxonomic Databases Working Group (TDWG) 2021.

This work was done as a Master thesis supported by the Institut de Systématique, Évolution, Biodiversité of the Paris Muséum National d'Histoire Naturelle.

\section{References}

Anonymous [International Commission on Zoological Nomenclature] (1999) International code of zoological nomenclature. $4^{\text {th }}$ Edition. International Trust for zoological Nomenclature, London, XXIX +306 pp.

Anonymous [World Wide Web Consortium] (2009) SKOS Simple Knowledge Organization System Reference. Available from: https://www.w3.org/TR/skos-reference/ (accessed 10 June 2021)

Anonymous [Technical Committee ISO/TC 46, Information and documentation, Subcommittee SC 9, Identification and description] (2011) ISO 25964-1:2011 Information and documentation-Thesauri and interoperability with other vocabularies_Part 1: Thesauri for information retrieval. Available from: https://www.iso.org/obp/ui/\#iso:std:iso:25964:-1:ed-1:v1: en (accessed 11 June 2021)

Anonymous [International Commission on Zoological Nomenclature] (2012) Amendment of Articles 8, 9, 10, 21 and 78 of the International Code of Zoological Nomenclature to expand and refine methods of publication. Bulletin of zoological Nomenclature, 69 (3), 161-169.

https://doi.org/10.21805/bzn.v69i3.a8.161

Anonymous [Technical Committee ISO/TC 46, Information and documentation, Subcommittee SC 9, Identification and description] (2013) ISO 25964-2:2013 Information and documentation-Thesauri and interoperability with other vocabularies_Part 2: Interoperability with other vocabularies. Available from: https:/www.iso.org/obp/ui/\#iso:std:iso:25964:-2:en (accessed 11 June 2021)

Anonymous [World Wide Web Consortium] (2015) Vocabularies, Available from: https://www.w3.org/standards/semanticweb/ ontology (accessed 10 June 2021)

Blanchard, R. (1905) Règles internationales de la nomenclature zoologique. International rules of zoological nomenclature. Internationale Regeln der zoologischen Nomenklatur. Rudeval, Paris, 64 pp.

Broughton, V. (2006) Essential thesaurus construction. Facet, London, 295 pp. https://doi.org/10.29085/9781856049849

Dmitriev, D.A. \& Yoder, M. (2020) NOMEN. Available from: https://github.com/SpeciesFileGroup/nomen (accessed 28 September 2021)

Dubois, A. (2000) Synonymies and related lists in zoology: general proposals, with examples in herpetology. Dumerilia, 4 (2), 33-98.

Dubois, A. (2005) Proposed Rules for the incorporation of nomina of higher-ranked zoological taxa in the International Code of Zoological Nomenclature. 1. Some general questions, concepts and terms of biological nomenclature. Zoosystema, 27 (2), 365-426. https://doi.org/10.11646/zootaxa.1337.1.1

Dubois, A. \& Ohler, A. (1996) Early scientific names of Amphibia Anura. I. Introduction. Bulletin du Muséum national d'Histoire naturelle, Series 4, 18 (3-4), 317-320.

Farber, P.L. (1976) The type-concept in zoology during the first half of the nineteenth century. Journal of the History of Biology, 9 (1), 93-119. [Publication date: Spring 1976] https://doi.org/10.1007/BF00129174

Hawksworth, D.L. (2010) Terms used in bionomenclature: the naming of organisms (and plant communities). Global Biodiversity Information Facility (GBIF), Copenhagen, 216 pp.

Linnaeus, C. (1758) Systema naturae per regna tria naturae, secundum classes, ordines, genera, species, cum characteribus, differentiis, synonymis, locis. Editio decima, reformata. Tomus 1. Laurentii Salvii, Holmiae [Stockholm], IV + 824 pp. https://doi.org/10.5962/bhl.title.542

Rousset, M. (2021) Opentheso webpage, Hypotheses. Available from: https://opentheso.hypotheses.org/ (accessed 31 May 2021)

Simpson, G.G. (1940) Types in modern taxonomy. American Journal of Science, 238, 413-431. https://doi.org/10.2475/ajs.238.6.413

Strickland, H.E., Henslow, J.S., Phillips, J., Shuckard W.E., Richardson, J., Waterhouse, G. R., Owen, R., Yarrell, W., Jenyns, L., Darwin, C., Broderip, W.J. \& Westwood, J.O. (1843) Series of propositions for rendering the nomenclature of zoology uniform and permanent, being the Report of a Committee for the consideration of the subject appointed by the British Association for the Advancement of Science. Annals \& Magazine of Natural History, Series 1, 11 (70), 259-275. https://doi.org/10.1080/03745484309445300

Wüster, W., Thomson, S.A., O’She, M. \& Kaiser, H. (2021) Confronting taxonomic vandalism in biology: conscientious community self-organization can preserve nomenclatural stability. Biological Journal of the Linnean Society, 133 (3), 645-670. https://doi.org/10.1093/biolinnean/blab009 
APPENDIX 1. List of the 60 publications searched for nomenclatural terms compiled in ZooNom.

Anonymous [International Commission on Zoological Nomenclature] (1999) International code of zoological nomenclature. 'Fourth edition'. International Trust for zoological Nomenclature, London, I-XXIX + 1-306 pp.

Alonso-Zarazaga, M.A. (2005) Nomenclature of higher taxa: a new approach. Bulletin of zoological Nomenclature, 62 (4), 189-199.

Ashlock, P.D. (1971) Monophyly and associated terms. Systematic Zoology, 20, 63-69. https://doi.org/10.2307/2412223

Ashlock, P.D. (1985) A revision of the Bergidea group: a problem in classification and biogeography (Hemiptera-Heteroptera: Lygaeidae). Journal of the Kansas entomological Society, 57 (4), 675-688.

Bourbaki, N. (1970) Éléments de mathématique. Livre 1. Théorie des ensembles. Herrmann, Paris, 1-337 pp.

Bruun, A.F. (1950) The Systema Naturae of the twentieth century. Science, 112, 342-343. https://doi.org/10.1126/science.112.2908.342.b

De Candolle, A.P. (1813) Théorie élémentaire de la botanique, ou exposition des principes de la classification naturelle et de l'art de décrire et d'étudier les végétaux. Déterville, Paris, I-VIII + 1-527 pp. https://doi.org/10.5962/bhl.title.39705

Dubois, A. (1982) Le statut nomenclatural des noms génériques d'Amphibiens créés par Kuhl \& Van Hasselt (1822): Megophrys, Occidozyga et Rhacophorus. Bulletin du Muséum national d'Histoire naturelle, Series A, 4, 261-280.

Dubois, A. (1984) La nomenclature supragénérique des Amphibiens Anoures. Mémoires du Muséum national d'Histoire naturelle, Series A, 131, 1-64.

Dubois, A. (1995) The valid scientific name of the Italian treefrog, with comments on the status of some early scientific names of Amphibia Anura, and some articles of the Code concerning secondary homonyms. Dumerilia, 2, 55-71.

Dubois, A. (1997) An evolutionary biologist's view on the science of biology. Alytes, 15 (3), 133-136.

Dubois, A. (2000) Synonymies and related lists in zoology: general proposals, with examples in herpetology. Dumerilia, 4 (2), 33-98.

Dubois, A. (2005) Proposals for the incorporation of nomina of higher-ranked taxa into the Code. Bulletin of zoological Nomenclature, 62 (4), 200-209.

Dubois, A. (2005) Proposed Rules for the incorporation of nomina of higher-ranked zoological taxa in the International Code of Zoological Nomenclature. 1. Some general questions, concepts and terms of biological nomenclature. Zoosystema, 27 (2), 365-426. https://doi.org/10.11646/zootaxa.1337.1.1

Dubois, A. (2006) Proposed Rules for the incorporation of nomina of higher-ranked zoological taxa in the International Code of Zoological Nomenclature. 2. The proposed Rules and their rationale. Zoosystema, 28 (1), 165-258. https://doi.org/10.11646/zootaxa.1337.1.1

Dubois, A. (2006) New proposals for naming lower-ranked taxa within the frame of the International Code of Zoological Nomenclature. Comptes rendus Biologies, 329 (10), 823-840. https://doi.org/10.1016/j.crvi.2006.07.003

Dubois, A. (2006) Incorporation of nomina of higher-ranked taxa into the International Code of Zoological Nomenclature: some basic questions. Zootaxa, 1337, 1-37. https://doi.org/10.11646/zootaxa.1337.1.1

Dubois, A. (2007) Phylogeny, taxonomy and nomenclature: the problem of taxonomic categories and of nomenclatural ranks. Zootaxa, 1519, 27-68. https://doi.org/10.11646/zootaxa.1519.1.3

Dubois, A. (2008) A partial but radical solution to the problem of nomenclatural taxonomic inflation and synonymy load. Biological Journal of the Linnean Society, 93, 857-863. https://doi.org/10.1111/j.1095-8312.2007.00900.x

Dubois, A. (2008) Le Code international de nomenclature zoologique: présentation, philosophie, règles majeures, problèmes actuels. In: Prat D., Raynal-Roques A. \& Roguenant A. (Eds.), Peut-on classer le vivant? Linné et la systématique aujourd'hui. Belin, Paris, pp. 355-402.

Dubois, A. (2008) Phylogenetic hypotheses, taxa and nomina in zoology. In: Minelli A., Bonato L. \& Fusco G. (Eds.), Updating the Linnaean heritage: names as tools for thinking about animals and plants. Zootaxa, 1950, pp. 51-86. https://doi.org/10.11646/zootaxa.1950.1.7

Dubois, A. (2010) La liaison organique taxinomie-collections-bibliothèques. Biosystema, 26, 21-44.

Dubois, A. (2010) Zoological nomenclature in the century of extinctions: priority vs. 'usage'. Organisms, Diversity \& Evolution, 10, 259-274. https://doi.org/10.1007/s13127-010-0021-3

Dubois, A. (2010) Retroactive changes should be introduced in the Code only with great care: problems related to the spellings of nomina. Zootaxa, 2426, 1-42. https://doi.org/10.11646/zootaxa.2426.1.1

Dubois, A. (2011) The International Code of Zoological Nomenclature must be drastically improved before it is too late. Bionomina, 2 (1), 1-104. 
https://doi.org/10.11646/bionomina.2.1.1

Dubois, A. (2011) A zoologist's viewpoint on the Draft BioCode. Bionomina, 3 (1), 45-62. https://doi.org/10.11646/bionomina.3.1.4

Dubois, A. (2012) The distinction between introduction of a new nomen and subsequent use of a previously introduced nomen in zoological nomenclature. Bionomina, (1)5, 57-80.

https://doi.org/10.11646/bionomina.5.1.2

Dubois, A. (2013) Zygoidy, a new nomenclatural concept. Bionomina, 6 (1), 1-25. https://doi.org/10.11646/bionomina.6.1.1

Dubois, A. (2015) Zoological nomina in the century of extinctions: new proposals. Bionomina, 8 (1), 11-53. https://doi.org/10.11646/bionomina.8.1.2

Dubois, A. (2015) The Duplostensional Nomenclatural System for higher zoological nomenclature. Dumerilia, 5, 1-108.

Dubois, A. (2016) The Duplostensional Nomenclatural System for higher zoological nomenclature: additional comments. $D u$ merilia, 6, 5-16.

Dubois, A. (2017) The nomenclatural status of Hysaplesia, Hylaplesia, Dendrobates and related nomina (Amphibia, Anura), with general comments on zoological nomenclature and its governance, as well as on taxonomic databases and websites. Bionomina, 11 (1), 1-48. https://doi.org/10.11646/bionomina.11.1.1

Dubois, A. (2017) Diagnoses in zoological taxonomy and nomenclature. Bionomina, 12 (1), 63-85. https://doi.org/10.11646/bionomina.12.1.8

Dubois, A. (2017) The need for reference specimens in zoological taxonomy and nomenclature. Bionomina, 12 (1), 4-38. https://doi.org/10.11646/bionomina.12.1.2

Dubois, A. (2020) Allocation of nomina to taxa in zoological nomenclature. Bionomina, 18 (1), 1-43. https://doi.org/10.11646/bionomina.18.1.1

Dubois, A. (2020) The status regarding publication date and availability of taxonomic works published online without proper Zoobank preregistration. Bionomina, 18 (1), 44-55. https://doi.org/10.11646/bionomina.18.1.2

Dubois, A., Bauer, A.M., Ceríaco, L.M.P., Dusoulier, F., Frétey, T., Löbl, I., Lorvelec, O., Ohler, A., Stopiglia, R. \& Aescht, E. (2019) The Linz Zoocode project: a set of new proposals regarding the terminology, the Principles and Rules of zoological nomenclature. First report of activities (2014-2019). Bionomina, 17 (1), 1-111. https://doi.org/10.11646/bionomina.17.1.1

Dubois, A. \& Bour, R. (2011) The authorship and date of the familial nomen Ranidae (Amphibia, Anura). Alytes, 27 (4), 154-160.

Dubois, A. \& Malécot, V. (2005) Glossaire: termes de taxinomie et de nomenclature utilisés dans ce volume. In: Dubois, A., Poncy, O., Malécot, V. \& Léger, N. (Eds.), Comment nommer les taxons de rang supérieur en zoologie et en botanique? Biosystema, 23, pp. 97-103.

Dubois, A. \& Ohler, A. (1996) Early scientific names of Amphibia Anura. I. Introduction. Bulletin du Muséum national d'Histoire naturelle, Series 4, 18 (3-4), 317-320.

Dubois, A. \& Ohler, A. (2009) The status of the amphibian nomina created by Merrem (1820) and Ritgen (1828). Zootaxa, 2247 (1), $1-36$. https://doi.org/10.11646/zootaxa.2247.1.1

Dubois, A. \& Ohler, A. (2019) The nomina Anura, Urodela, Ecaudata and Caudata, credited to 'Fischer von Waldheim, 1813', do not exist, with comments on the nomenclature of higher zoological taxa and on the authorships and dates of other amphibian nomina. Bionomina, 14, 1-68. https://doi.org/10.11646/bionomina.14.1.1

Dubois, A., Ohler, A. \& Pyron, R.A. (2021) New concepts and methods for phylogenetic taxonomy and nomenclature in zoology, exemplified by a new ranked cladonomy of recent amphibians (Lissamphibia). Megataxa, 5 (1), 1-738. https://doi.org/10.11646/megataxa.5.1.1

Dubois, A. \& Raffaëlli, J. (2009) A new ergotaxonomy of the family Salamandridae Goldfuss, 1820 (Amphibia, Urodela). Alytes, 26 (1-4), 1-85.

Dubois, A. \& Raffaëlli, J. (2012) A new ergotaxonomy of the order Urodela Duméril, 1805 (Amphibia, Batrachia). Alytes, 28 (3-4), 77-161.

Frétey, T., Dewynter, M. \& Ohler, A. (2018) Onymotopes in zoological nomenclature: some additional terms, with fixation of a lectonymotope for Xenopus petersii Bocage, 1895 (Amphibia, Anura). Bionomina, 13, 37-50. https://doi.org/10.11646/bionomina.13.1.3

Hawksworth, D.L. (2010) Terms used in bionomenclature: the naming of organisms (and plant communities). Global Biodiversity Information Facility (GBIF), Copenhagen, 216 pp.

Hennig, W. (1950) Grundzüge einer Theorie der phylogenetischen Systematik. Deutscher Zentralverlag, Berlin, VII + 370 pp.

Knapp, S., Lamas, G., Nic Lughadha, E. \& Novarino, G. (2004) Stability or stasis in the names of organisms: the evolving codes of nomenclature. Philosophical Transactions of the Royal Society of London B, 359, 611-622. https://doi.org/10.1098/rstb.2003.1445

Lidén, M., Oxelman, B., Backlund, A., Andersson, L., Bremer, B., Eriksson, R., Moberg, R., Nordal, I., Persson, K., Thulin, M. 
\& Zimmer, B. (1997) Charlie is our darling. Taxon, 46 (4), 735-738. https://doi.org/10.2307/1224479

Meyer, A. (1926) Logik der Morphologie im Rahmen einer Logik der gesamten Biologie. Julius Springer, Berlin, VII + 290 pp. https://doi.org/10.1007/978-3-642-50733-5_1

Pyle R. L. (2004) Taxonomer: a relational data model for managing information relevant to taxonomic research. PhyloInformatics, 2004 (1) 1-54. https://doi.org/10.5281/ZENODO.59790

Simpson, G.G. (1940) Types in modern taxonomy. American Journal of Science, 238, 413-431. https://doi.org/10.2475/ajs.238.6.413

Smith, H.M. \& Pérez-Higareda, G. (1986) Nomenclatural name-forms. Systematic Zoology, 35 (3), 421-422. https://doi.org/10.2307/2413392

Smith, H.M. \& Smith, R.B. (1973) Chresonymy ex synonymy. Systematic Zoology, 21, 445. [1972] https://doi.org/10.2307/2412440

Sneath, P.H.A. (1962) The construction of taxonomic groups. In: Ainsworth, G.C. \& Sneath, P.H.A. (Eds.), Microbial classification: twelfth Symposium of the society for General Microbiology, held at the Royal institution, London, April 1962. Cambridge University Press, Cambridge, pp. 289-332.

Starobogatov, Y.I. (1991) Problems in the nomenclature of higher taxonomic categories. Bulletin of zoological Nomenclature, $48(1), 6-18$. https://doi.org/10.5962/bhl.part.663

Van Regenmortel, M.H.V. (2016) Classes, taxa and categories in hierarchical virus classification: a review of current debates on definitions and names of virus species. Bionomina, 10 (1), 1-21. https://doi.org/10.11646/bionomina.10.1.1

Wüster, W., Thomson, S.A., O’She, M. \& Kaiser, H. (2021) Confronting taxonomic vandalism in biology: conscientious community self-organization can preserve nomenclatural stability. Biological Journal of the Linnean Society, 133 (3), 645-670. https://doi.org/10.1093/biolinnean/blab009' 